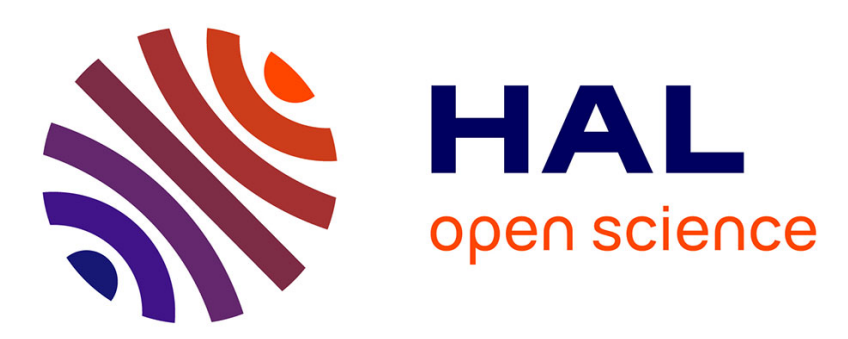

\title{
The discovery of new rock paintings in the Horn of Africa: the rockshelters of Las Geel, Republic of Somaliland.
}

Xavier Gutherz, Jean-Paul Cros, Joséphine Lesur

\section{- To cite this version:}

Xavier Gutherz, Jean-Paul Cros, Joséphine Lesur. The discovery of new rock paintings in the Horn of Africa: the rockshelters of Las Geel, Republic of Somaliland.. Journal of African archaeology, 2003. hal-02155252

\section{HAL Id: hal-02155252 \\ https://hal.science/hal-02155252}

Submitted on 26 Jun 2019

HAL is a multi-disciplinary open access archive for the deposit and dissemination of scientific research documents, whether they are published or not. The documents may come from teaching and research institutions in France or abroad, or from public or private research centers.
L'archive ouverte pluridisciplinaire HAL, est destinée au dépôt et à la diffusion de documents scientifiques de niveau recherche, publiés ou non, émanant des établissements d'enseignement et de recherche français ou étrangers, des laboratoires publics ou privés. 


\title{
The discovery of new rock paintings in the Horn of Africa: the rockshelters of Las Geel, Republic of Somaliland
}

\author{
Xavier Gutherz, Jean-Paul Cros \& Joséphine Lesur
}

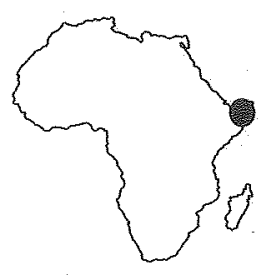

Abstract

An archaeological survey was carried out by a French team in November and December 2002 in the Somaliland Republic. The objective was the search for rock shelters and caves containing stratified archaeological infills capable of documenting the period when production economy appeared in this part of the Horn of Africa (circa $5^{\text {th }}$ and $2^{\text {ind }}$ millenia B.C.). The Las Geel site, a granite rock sheltering about ten shelters decorated with polychrome paintings, was discovered in the course of the survey. These paintings, in an excellent state of preservation, mainly represent humpless cows with large lyre-shaped or arched horns and the neck decorated with a kind of "plastron". The cows are accompanied by stocky human figures with spindel-shape legs and raised arms. There are also some figures of canidae placed beside men, a single giraffe and some antelopes. The evident superposition of several graphic styles will no doubt make it possible to establish a chronology of Neolithic or Protohistoric rock art in this part of the Horn of Africa. Through the abundance of its paintings, their quality, the originality of the type of representation of bovines and human figures, the Las Geel site will henceforth take its place among the major Holocene sites of rock art in this region of Africa. A future mission planned for November 2003 will make it possible to undertake a detailed study of these paintings and their archaeological context. This note constitutes a preliminary presentation of this exceptional discovery
Résumé

Une mission de prospection archéologique a été réalisée par une équipe française en novembre et décembre 2002 en République de Somaliland. Elle avait pour objectif la recherche d'abris-sous-roche et de grottes contenant des remplissages archéologiques stratifiés susceptibles de documenter la période où est apparue l'économie de production dans cette partie de la Corne de l'Afrique (circa $5^{e}-2^{e r}$ millénaires av. J.-C.). Au cours de cette mission, fut découvert le site de Las Geel, un rocher granitique qui abrite une dizaine d'abris ornés de peintures polychromes. Ces peintures, dans un excellent état de conservation, représentent principalement des vaches à dos plat et grandes cornes en lyre ou en arceaux, au cou orné d'une sorte de "plastron". Ces vaches sont accompagnées de personnages trapus possédant des jambes fusiformes et levant les bras. Il existe aussi quelques figurations de canidés placés aux côtés des hommes, une seule girafe et quelques antilopes. La superposition évidente de plusieurs styles de graphisme permettra sans doute d'établir une chronologie de l'art rupestre néolithique ou protohistorique dans cette partie de la Corne de L'Afrique. Par l'abondance de ses peintures, leur qualité exceptionnelle, l'originalité du type de représentation des bovinés et des personnages, le site de Las Geel figurera désormais parmi les sites majeurs de l'art rupestre holocène de cette région de l'Afrique. Une prochaine mission permettre d'entreprendre une étude détaillée de ces peintures et de leur environnement archéologique. Cette note constitue une présentation préliminaire de cette découverte exceptionnelle.

Keywords: Rock art, neolithic, protohistoric, Somaliland, Horn of Africa

\begin{tabular}{|c|c|c|}
\hline Xavier Guthere' & Jean-Paul Cros ${ }^{2}$ & Josephine Lesur \\
\hline Unversite Paul Valery-Monipellier 111 & 5, ne du 14 unillet & Mirserim national disistone Naturelle \\
\hline Route de Mende & 34420 Villeneuve-1es Beziers & FSA 8045 \\
\hline 34109 Montpellier cedex 5 & Prance & 55. the dia Buffor \\
\hline France & E-mail: jeanpauleros 0 wanadoo fi & 75005 Palls \\
\hline I.nail x.gutherz@wanadoo.tr & & France \\
\hline
\end{tabular}




\section{Circumstances surrounding the discovery}

During an archaeological survey carried out in November and December 2002 in the Republic of Somaliland ${ }^{4}$, we were driven the $4^{\text {th }}$ of December to the site of Las Geel on our way back to Hargeisa. We were informed of the site by an inhabitant of Daarbudhuq, a small village on the national road between Hargeisa and Berbera; he then proceeded to take us there. The small red granite massif of Las Geel is located $4 \mathrm{~km}$ west of the road from Hargeisa to Berbera (Fig. 1). This rocky massif stands out from a large granitic Plateau carved out by wadis (Fig. ). At the foot of the rock of Las Geel is the confluence of two wadis. One can easily understand the name of this place, given the presence of temporary water foreshores and of a permanent water table close to the surface of the wadis. Indeed, the Somali name means: „The dromedaries' waterhole". Nowadays, this name has changed to "Las Gaal“ but, following our somalilandese guides" advice, we have chosen to use the original spelling which has a more significant meaning.

\section{Physical Description}

The rock of Las Geel (Fig. 2) comprises around 20 modest-sized shelters opening in all directions. The surroundings of the massif are strewn with lithic industry (flint flakes, nucleus and tools) to which we will return later.

The paintings are only present in the shelters on the Eastern side. However, on the Southern side, some

1 Head of the mission, professor at the University Paul ValéryMontpellier III and member of the UMR 6636 (ESEP -MMSH, Aix-en-Provence).

2 Medical doctor, paléoanthropologist, associate researcher at the UMR 7041, Nanterre (team "Afrique, sociétés et environnement $t^{i c}$ ).

3 PhD student at the University of Paris 1 and nember of the team ESA 8045 "Archéoozologie et histoire des sociétés", MNHN, Paris.

4 This mission was made possible thanks to a research grantfrom the French Ministry of Foreign Affairs and also as a result of the kindness of Somalilandese Authorities, especially $M$. Osman Ali Bile, Minister of Culture and Tourism whom we warmly want to thank, as well as his collaborators. Our thanks also goes to $\mathrm{M}$. Mohamed Omar Ismaël and Mohamed Abdi Ali for their precious help in the field. worn away marks were observed, whereas in the overhanging shelters on the western side, there is no sign that paintings had ever existed.

The painted panels are distributed among approximately ten shelters, the larger ones of which have a maximum depth of 5 meters and a width reaching 10 meters. These natural shelters, which have been eroded by the combined effects of thermoclasty, corrosion and wind erosion, are distributed on three levels. The upper level has three shelters. Between these shelters are two collections of paintings, one located slightly higher under a small overhang, the other in an alcove. Toward the north, about ten meters from this first set, as well as in the southern part, worn away red-painted marks on subvertical walls certify to the presence of ancient painted panels. In these two cases, the verticality of the stands and the lack of overhang or their collapse, did not allow for the preservation of the paintings.

The intermediate level comprises a decorated shelter as well as a bell-shaped alcove where peculiar themes are represented that we will describe later. Finally, on the lower level, the two last shelters are very richly painted. In one of these, there are very singular themes of human and animal representations. We were only able to observe the other one from a distance using binoculars because of the presence of several large wasps' nests which forbade our approach.

\section{The paintings}

In each shelter, on each panel, animal and human representations dominate the themes of the paintings. These representations are a combination of a small number of monochrome figures, and many more polychrome figures (Fig. 3). The colours used are, in order of frequency, red ochre, white, yellow ochre and, more seldom, black.

\section{Bovine}

The many bovines painted at Las Geel are cows with the udder and the four teats clearly drawn (Fig. 4, 5 and following). They are all humpless cows. Their coat is either unicolor or piebald. The long horns are mainly claw-shaped (Fig. 4), more seldom straight or lyre-shaped (Fig. 3) and often completely painted white; their tips are frequently painted, reddish-brown" and are sometimes decorated with undulating red lines (Fig. 3). The very short tails are seldom represented. 


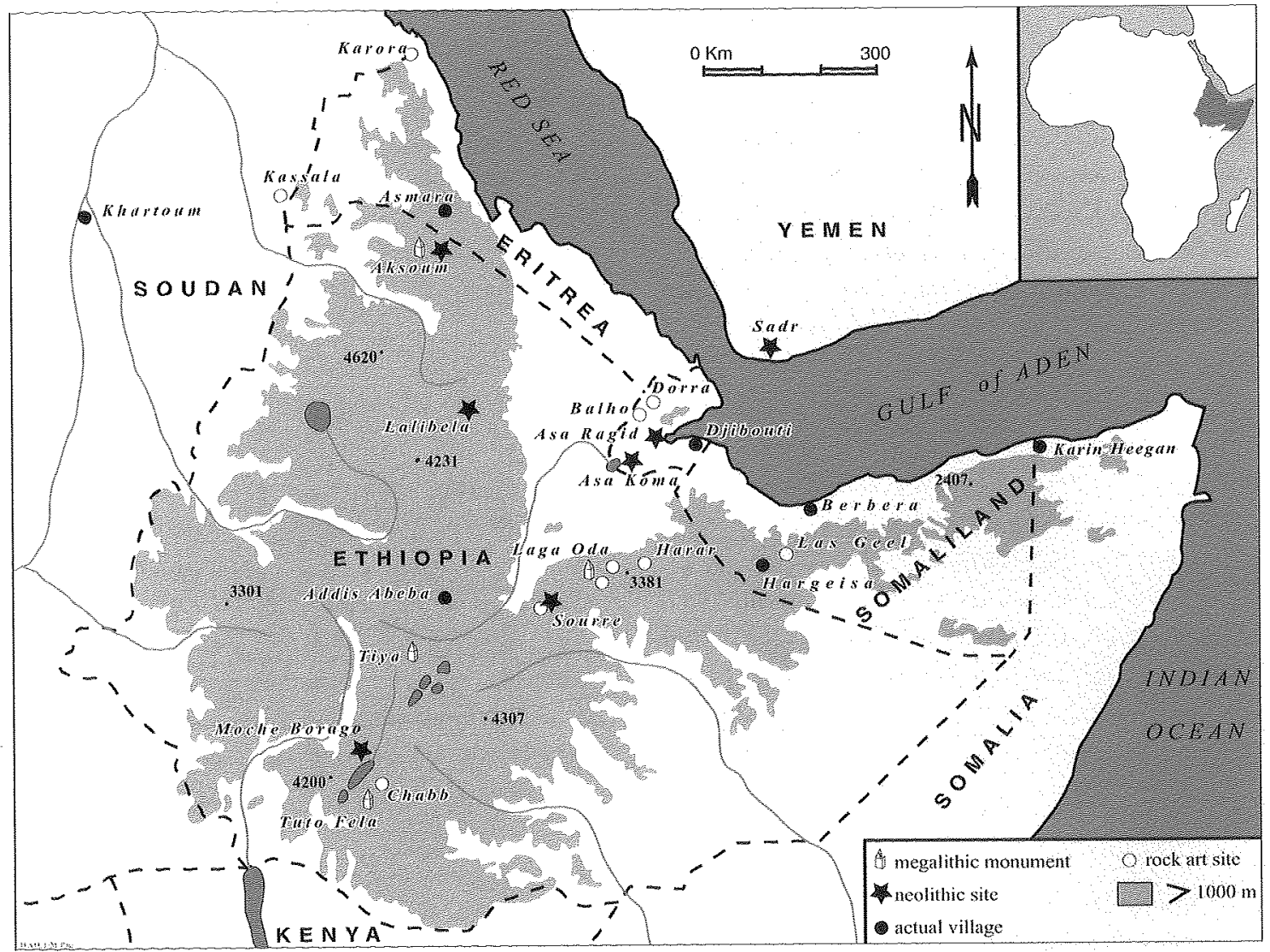

Fig. 1. Map of the Horn of Africa with location of the principal neolithic and rock art sites.

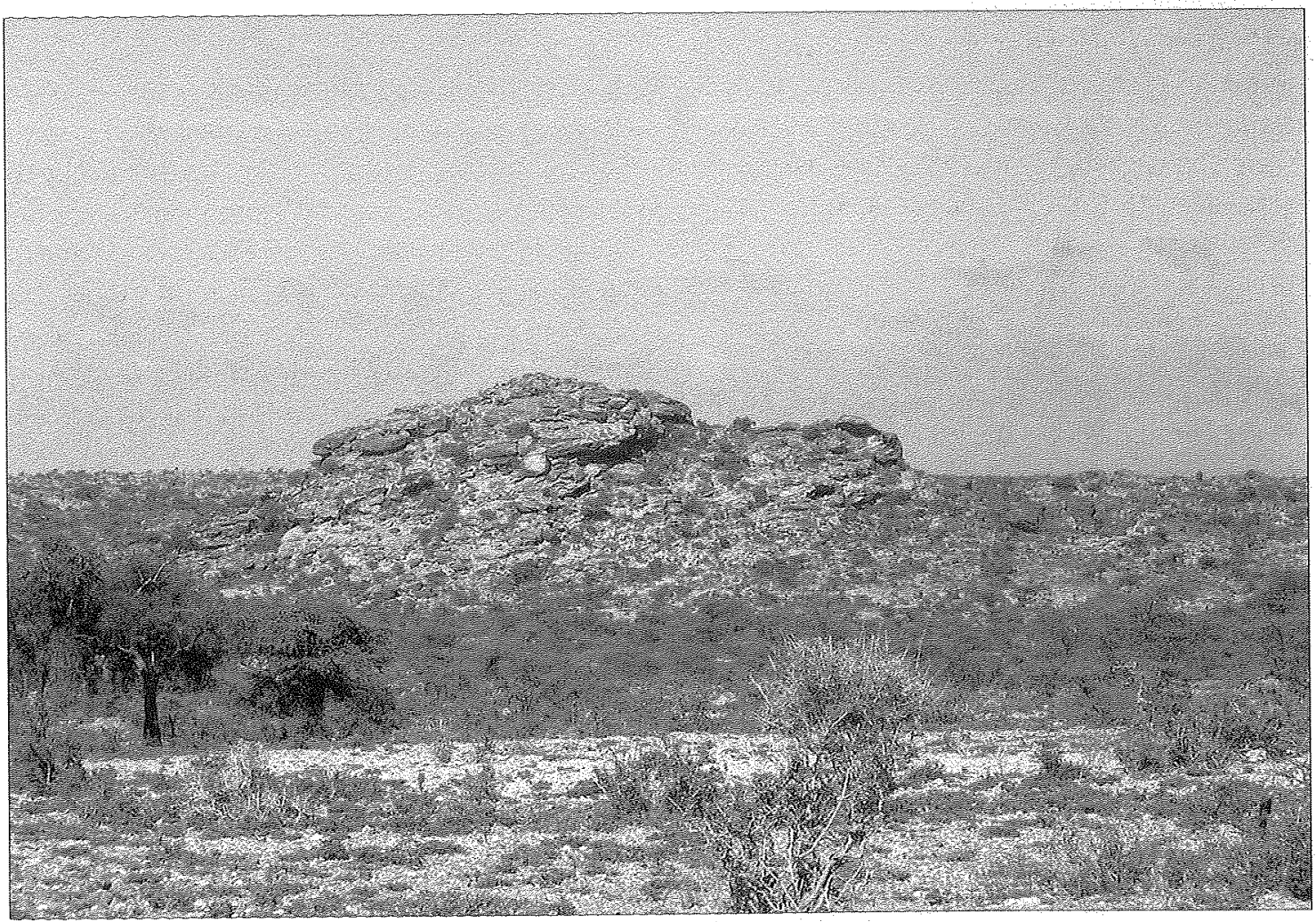

Fig. 2. General view of Las Geel site. 
Legs are not differentiated because the animals' bodies are drawn in profile.

Most surprising is the way the necks and heads are drawn. The necks are long, filiform and represented by a stroke that extends to the line of the animal's back. They have at their distal end a small head in a shape of either a large round vase or a bell. The heads are painted as though seen from above. They are sometimes surrounded with small radial strokes or dots. So a simple stroke extends from the dorsal line to the head, which seems to stand apart from the body. Undemeath the neck there is a subrectangular area with a rounded rostrum at the bottom toward the front. The internal space of this area with smooth angles is painted in different ways: either it is left empty leaving a distinguishable neck line, or it is painted evenly, or decorated with vertical stripes (very seldom horizontal) painted alternately in two colours (usually in red and white, in one case in black and white).

Concerning the size, even though we did not carry out precise measurements because of lack of time, we can estimate that the bovines have an average length of around 40 to $50 \mathrm{~cm}$ and a height of 20 to $30 \mathrm{~cm}$. Some of the animals are smaller (about $20 \mathrm{~cm}$ long).

Although each panel comprises at least three or four animals, and up to 15 on the most crowded panels, there is no representation of a herd, as there are in other decorated sites of the Horn of Africa, such as the closest one, the rock shelter of Karin Heegan near Boosaaso, $300 \mathrm{~km}$ away from Las Geel (see ,Comparative elements").

\section{Human Representations}

Many anthropomorphs are painted on the walls of some shelters, but they are less numerous than the bovines. The thorax is wide, and dressed with a kind of "shirt" sometimes drawn with vertical stripes (Fig. 4, $6,7)$. The lower limbs are spindle-shaped, merged or separated by a simple stroke or a vertical gap. The upper limbs are filiform and always spread open, making the body appear cross-shaped. The head is small, either punctiform, rounded, or turned sideways and set above a truncated neck, on which are sometimes painted horizontal strokes appearing like neck rings one on the top of the other. This head is sometimes surrounded by a pointed „crown“ or by small radial dashes. In some cases, a kind of feather head-dress appears on one side of the top of the head. These characters some- times carry a bow, a stick or possibly a small shield. They are systematically associated with the bovines and are placed either under the neck (Fig. 4), under the belly (Fig. 5), or more seldom behind the rump. Besides the fact that they are sometimes with canids (Fig. 7), these characters are never drawn with any link to each other and no group activity scenes are detectable.

\section{Other Animal Representations}

Apart from the cows, the most represented animal is certainly the dog, or at least a canid with a curved tail and pointed ears (Fig. 7). These dogs are often drawn next to the human representations.

Other animals are much more rarely painted. There are some figures which appear to be antelopes, with backs that slope down towards the rump and with an arch-shaped belly line (see engravings at Dorra and Balho in Djibouti), on the panel with the only representation of a giraffe (Fig. 8 ).

\section{Signs}

These shelters also contain painted signs that are non-figurative or not easily interpretable. Groups of dots or dashes are associated with some bovines and humans. They are painted like a crown around their heads. In a unique scene in a small alcove with concave walls, five lined-up vertical strokes are represented in red ochre without any lateral appendage (Fig. 6 ). Each stroke ends at the top with a circle painted in brownish black. These filiform ,subjects" are placed in front of, or partly under, a cow's neck. But is this the stylized representation of filiform characters as it exists in the Harrar region? Here, in any case, neither upper nor lower limbs nor the sex are drawn. We have observed that the cow's neck has a beautiful decoration of vertical white stripes alternately with brown black stripes. Within one of the white stripes, round brown-black spots are painted, maybe significantly close to the ,heads". Under the cow, we find a large character with raised arms, whose left arm seems to touch the five teats of the cow, drawn one under the other. Is there any semantic link between these three subjects?

On the panel in the most northern shelter of the lower level, one can see elongated, sticks" decorated with transversal white stripes. At least one has 




Fig. 3. Polychrome panel of the upper level. Note the inner decoration of the horn of the ochre cow.

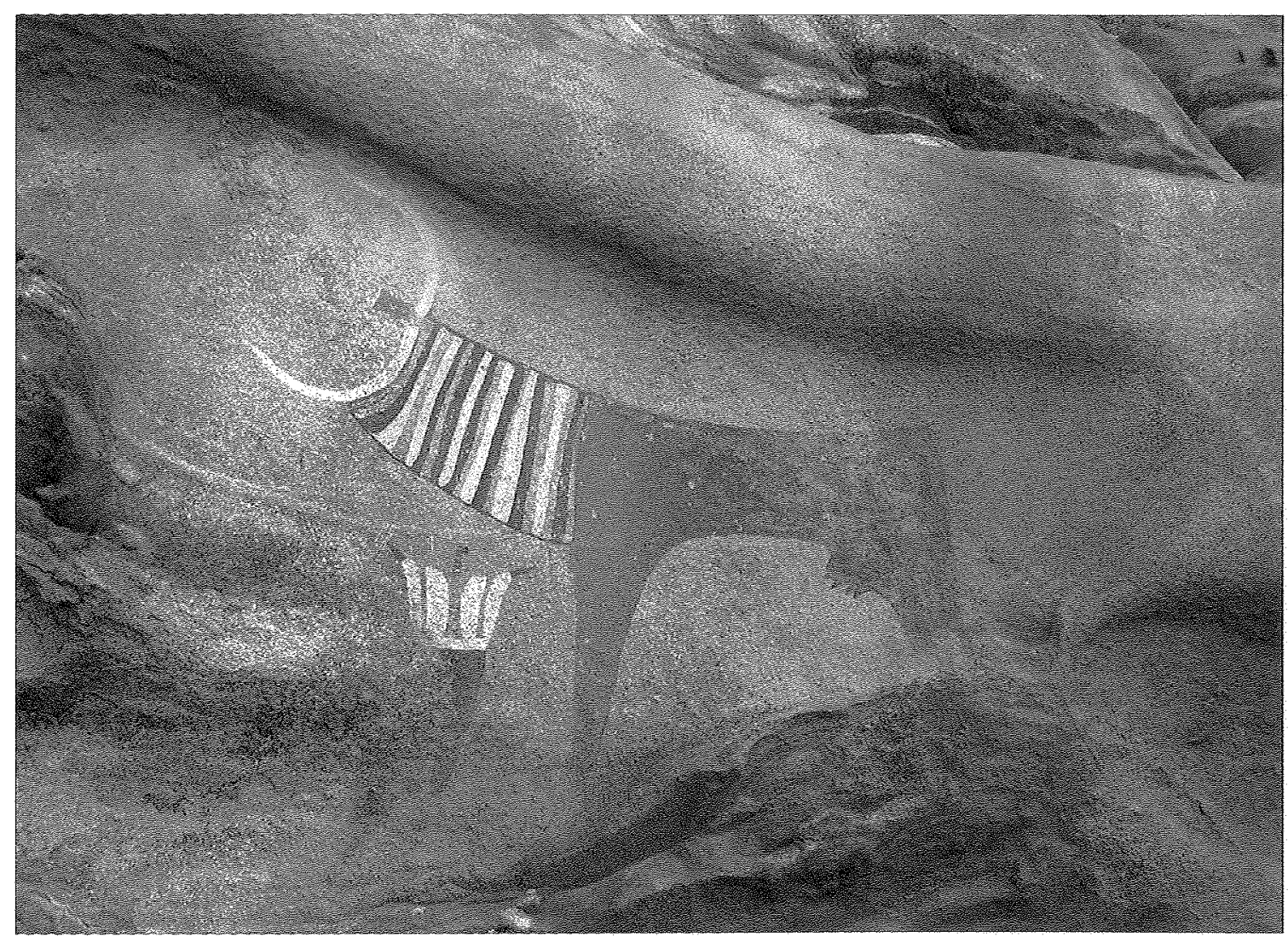

Fig. 4. Central shelter of the upper level: combination of decorated cow and human figure: Note the bovine's plastron. 


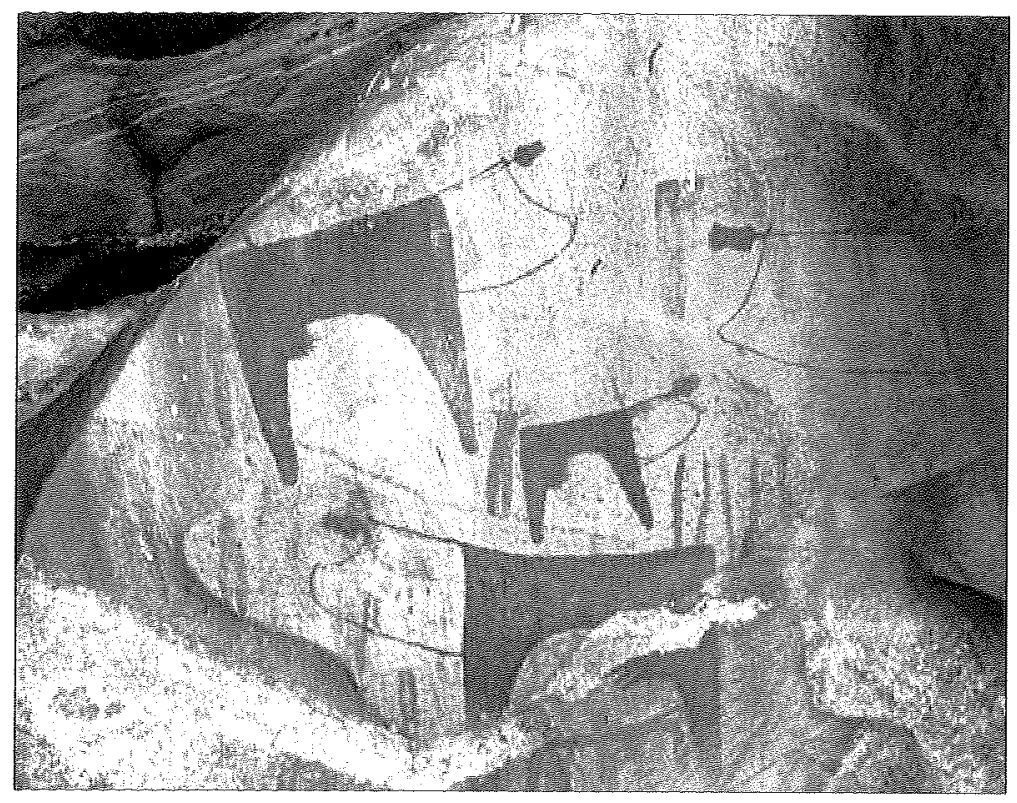

Fig. 5. Detail of the alcove in the upper level: note the superposings.

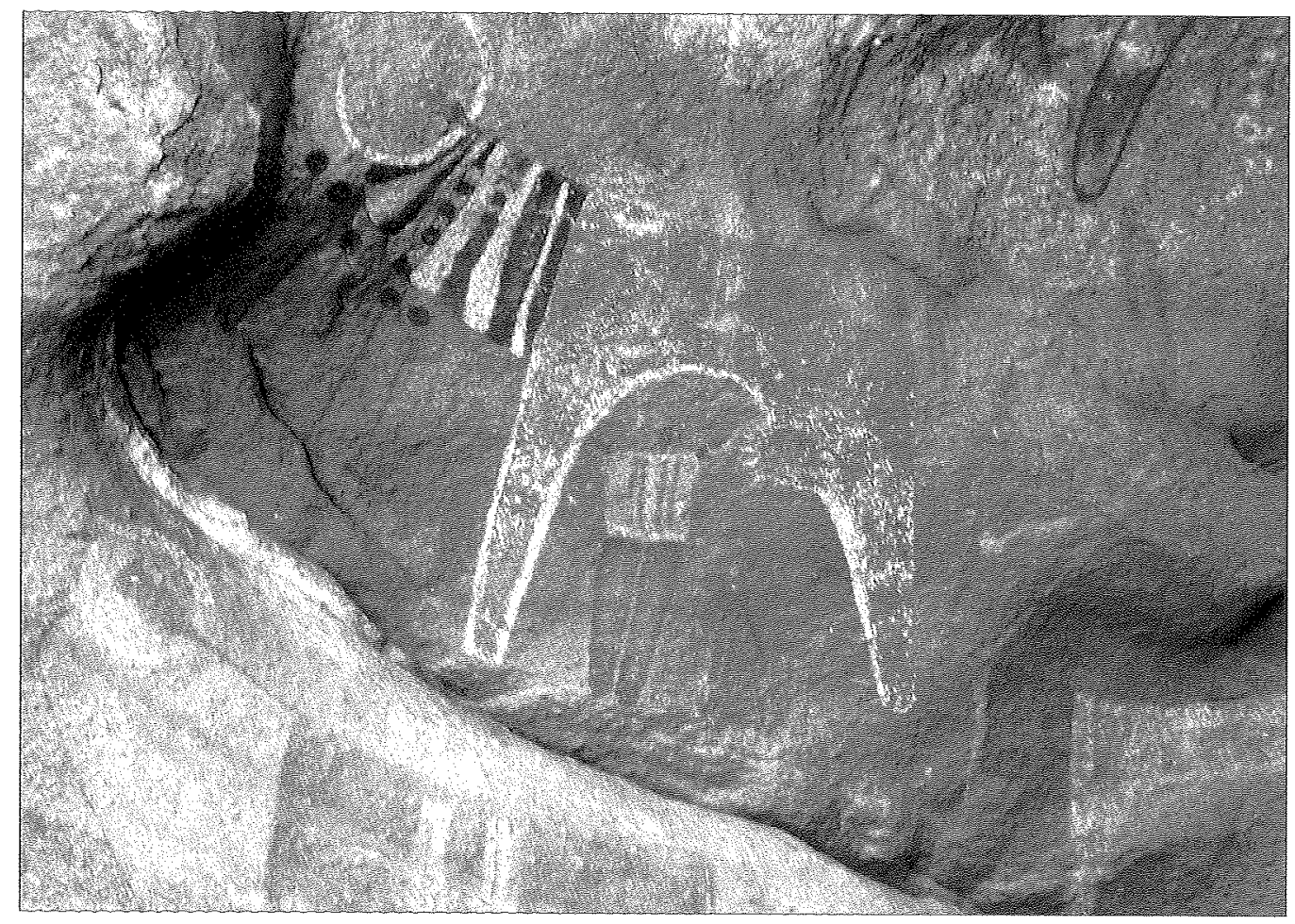

Fig. 6. Composition human-cow in the alcove of the intermediate level. Note the richly decorated plastron and the vertical strokes with circles at the top under the cow's neck.

at its upper end a ,crown" of dashes; it could be a very stylized human representation. There are, in some places, and especially in the alcove of the upper level, some fingerprints painted in red or yellow ochre, sometimes superimposed with animal figures.
Finally, we can observe other signs or other figurations that are not easily interpretable. For instance, in the big alcove, some kind of pins with annular heads, on another panel a kind of decorated "helmet" and yet on another probably an animal which was not identified but could be a bustard. 


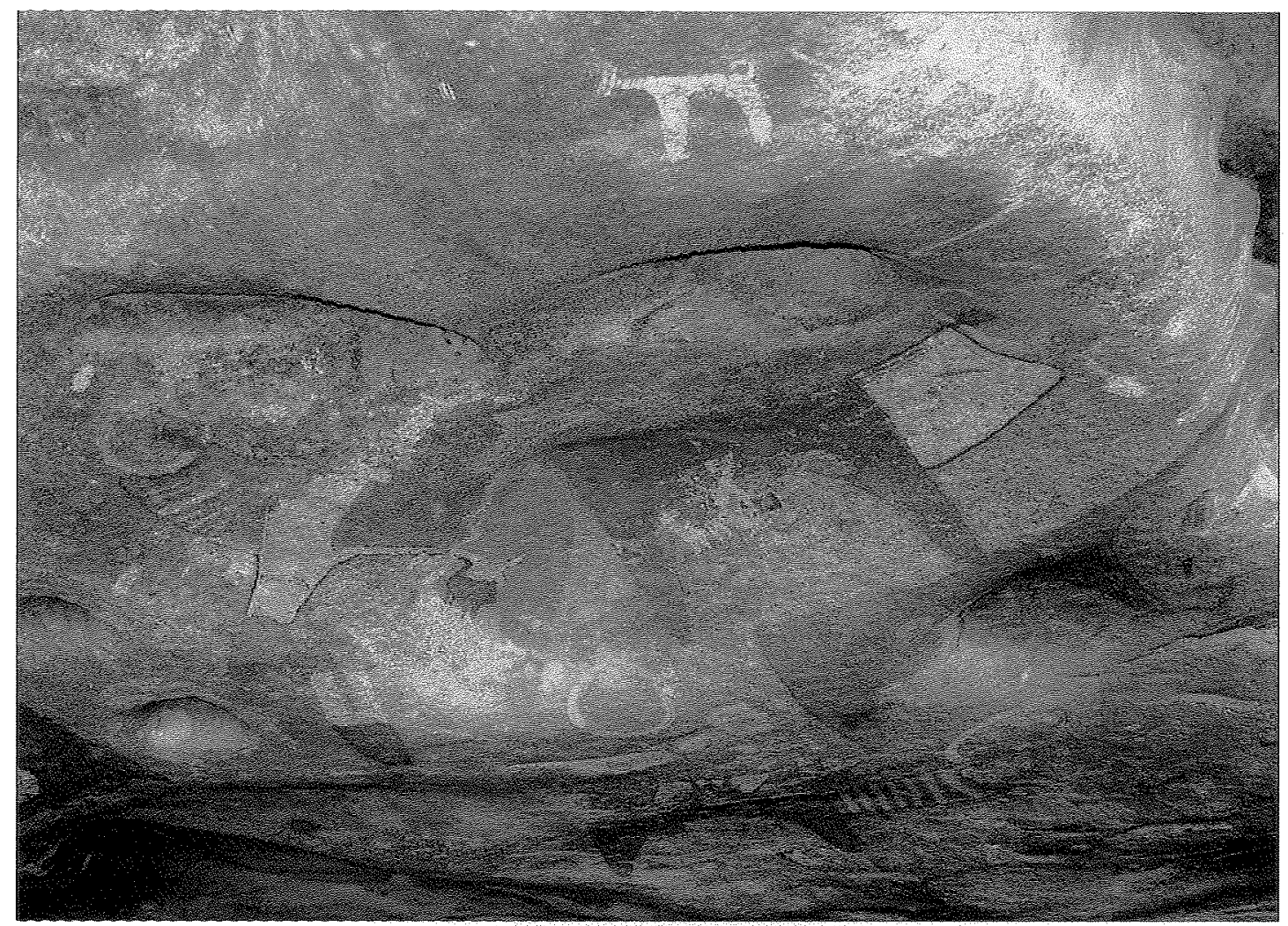

Fig. 7. Polychrome panel at the ceiling of a shelter at the upper level Note the figuration of a withe dog with decorated neck.

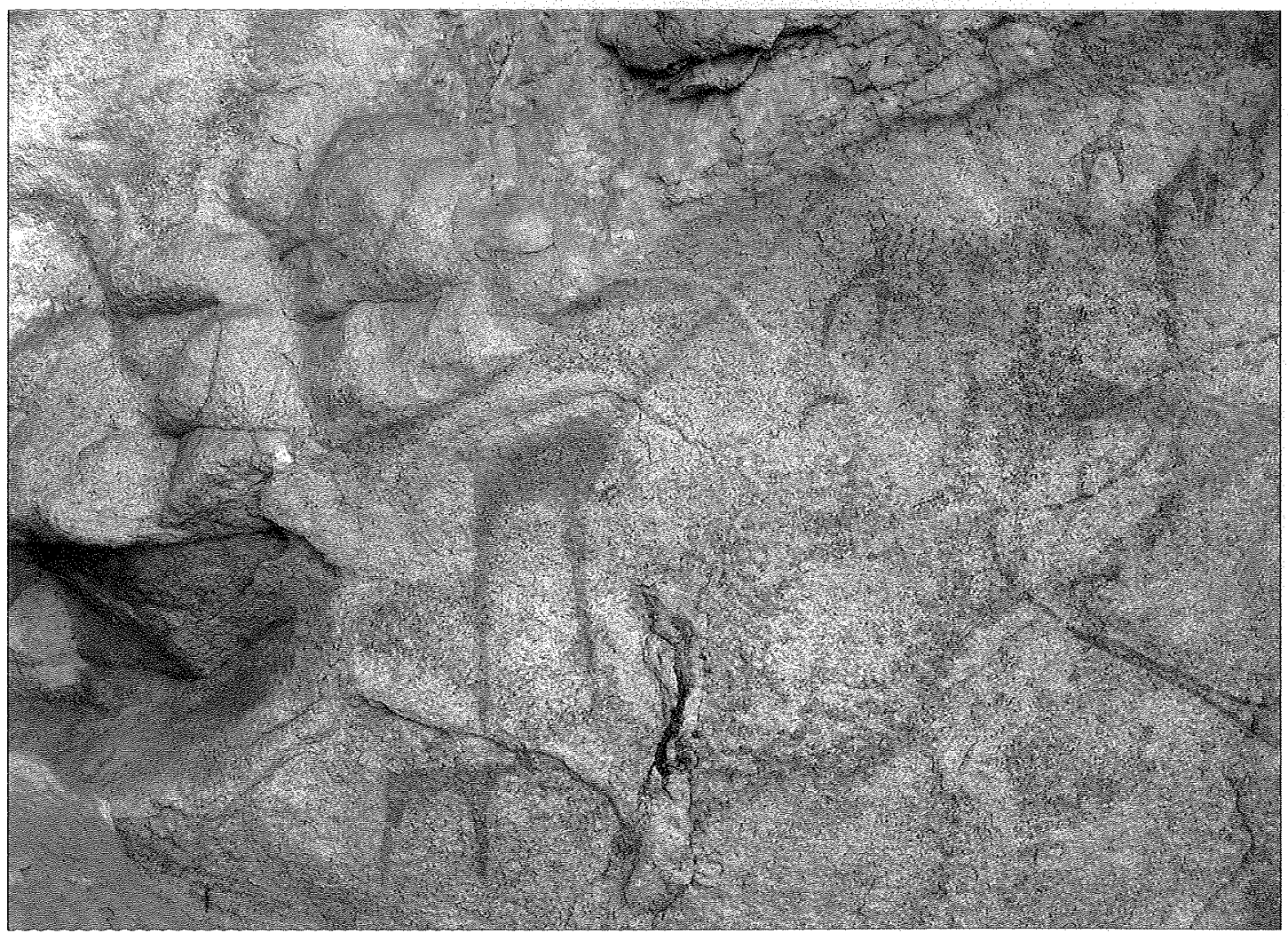

Fig. 8. The northern shelter at the upper level: the only representation of a giraffe and same antelopes. 


\section{First chronological and cultural observations}

\section{Chronological problems}

In a general way, the paintings of Las Geel are mainly connected through the execution ,period" whose unity can be recognized through a distinctive style. However, one can notice cases where paintings are obviously superimposed. There is one case on the large panel with the red cows in the alcove of the upper level (Fig. 5). On this panel, some human and animal representations, as well as simple vertical strokes with worn away colours, have been covered up by the large female bovines painted in red ochre, whose preservation is remarkable. Other similar cases can be seen here and there on the site.

If we consider the way the bovines were drawn, some panels allow a glimpse of a local evolution of the graphism from a style very close to the Arabo-Ethiopian one of Harrar and that of Chabbe-Galma, to the style of the recent phases of Las Geel.

It is of course very difficult to attribute a precise age to the paintings of Las Geel, in the present state of analysis. When we come to the comparisons section, we will see that, in spite of their obvious originality, the paintings are bound to a pan-regional style that is usually dated from the III ${ }^{\mathrm{d}}$ and $\mathrm{II}^{\mathrm{d}}$ millenia $\mathrm{BC}$, the period of the outbreak and development of cattle breeding in the Horn of Africa (Joussaume 1981, 1989). The many lithic tools present on the site, on the ground of some shelters and on the slope at the bottom of the latter, must be analysed but their chronological position will be difficult to define. Indeed, at first sight, a white patina, present on some pieces and missing on others, allows us to think that there are different occupation phases, which may take us back to the painted walls. Moreover, the chrono-typological classification of the Holocene lithic industry from Somaliland and Somalia has not improved since Clark's studies in the 1950's and of which S.A. Brandt reminded recently that they should be completely redone (BRANDT 1986). In fact that is one of the goals that we set ourselves by starting a research program in Somaliland. The second problem that appears here, as well as in many others dwelling sites we saw during this field trip, is the complete lack of ceramic. If we give a Neolithic or Protohistoric age, we must admit that these pastoral groups lived in the area without using pottery.

We must mention here the very late dates obtained by BRANDT on wood charcoal coming from a test pit dug at the entrance of Karin Heegan shelter (BRANDT et al. 1984). These dates of 1600 and $2100 \mathrm{BP}$ are surprising if we put them in relation with the paintings (humpless cattle and lack of camel). The archaeological material found in the $2 \mathrm{~m}^{2}$ pit is very poor and insignificant. It is thus possible that these dates correspond to an occupation more recent than the creation of the paintings.

\section{Main elements of Las Geels themes}

What first strikes one in this very rich set of panels is the prominent role of bovines. These figures are larger than any other animal, even bigger than the characters pictured next to them. The very original design of the neck and head of those animals allows us to interpret it as a symbolic representation, except if we consider that it could represent a piece of fabric or leather resting on the neck of the animals during special ceremonies. That is why, in the case of Las Geel, it is difficult to endorse the opinion of some authors (BOUAKAZE-KHAN 2002) who interpret those decorations under the bovines neck as the figuration of fatty folds (shelter of Ourso in Harrar). At Las Geel, the special decoration of the neck, in addition to the schematic representation of the head, confers to this body part a special importance whose meaning escapes us but probably belongs to the symbolic field. In a sense, this contradicts the realism that characterizes the representation of the udder and that could suggest the importance of milk in the diet.

\section{Comparative elements}

Concerning the human representation, we could find but one comparative site in the area. This is the shelter of Karin Heegan, located $300 \mathrm{~km}$ to the NorthEast, near Boosaaso in Somalia (BRANDT \& CARdER 1987). In this shelter, richly decorated with bovines, we noticed at least two characters exactly similar to those of Las Geel. The other anthropomorphic characters from the rest of the sites in the Horn of Africa bear many similar (?) aspects but none of them can be compared directly with the figures of Las Geel.

The manner of representing female bovines, except for the very special design of the neck and the head, takes us back to one or several stylistic spheres known in the Horn of Africa. For the head and neck, here again, only one comparative site can be used. Indeed at Karin Heegan, one of the many bovines has a decorated plastron joining the breast to the horns, ex- 
actly like at Las Geel. This connection is reinforced by the presence next to this bovine of the human character mentioned before. Nevertheless, even if all the sites panels are not reproduced in the article, it seems that this Figure is an exception. Indeed, the other bovines of Karin Heegan lack the same attributes.

The Arabo-Ethiopian style defined by CERviceK (1979) covers a vast area which comprises the Arabian peninsula and the whole Horn. In that style, the bovines would be represented according to persistent canons, notwithstanding many variations. These are long-horned humpless bovines represented in profile with front and back limbs only drawn by thick strokes. However the neck, the head and the horns are seen from back or above. If we consider only these general criteria, there is no doubt that bovines of Las Geel belong to this style family.

If we compare the cows of Las Geel with those carved or engraved in the Ethiopian Sidamo region, both similarities and differences arise. Nowhere at Las Geel does the vertical dash at the distal end of the paws exist which is found on the carved animals of Chabbé and on the painted animals of Laga Oda, and which probably represents the hoof. Besides, we cannot endorse the recent opinion of J. L. Le Quellec who proposes to make the presence or the lack of this dash a discriminating element between the Chabbe-Galma style and the Laga-Oda-Sourre style (LE QueLLEC \& Gezachew 2001). The general outline is drawn in the spirit of Chabbe-Galma style but with notable changes: the Las Geel rump is straight while it is curved at Chabbé; the udders' teats are very long on the Chabbé engravings and the udder is out of proportion compared with the body volume. At Las Geel, the teats are much less ,exuberant" than at Chabbé and the udder proportions remain compatible with the rest of the body. Finally it is the way of representing the horns that link the two styles even if the Chabbé cows often show a dissymetry between the right and the left horn which makes a kind of a ,L".

As for the comparisons that we can attempt with the bovines from Harrar, we should remember, for instance, the presence of straight rumps in both cases and a strong similarity in the general outline of the animals. But the most interesting common point, with regard to the peculiarity of the bovines representation at Las Geel, remains the decoration of the animals' neck. This stylistic feature appears of course in a very discreet way in the cave art of Harrar so that it never drew researchers' attention. Today, with the discovery of Las
Geel, it takes on another meaning. It is mainly at Laga Oda, but also at Sourré, Goda Dassa, Goda Allele and Ourso (BOUAKAZE-KHAN 2002) that we can observe bovines wearing decorations on or under their neck. Those on the neck consist in a succession of superimposed strokes that stripes the neck as stacked necklaces. These are the ornamentations that can be compared with the ,plastrons" of Las Geel. The others consist in a line of subrectangulary joined appendages placed exactly at the slot of this anatomic part very developed in some East-African bovines breeds today (called the ,dewlap", a kind of skin fringe hanging under the neck). Apart from the painted sites of Harrar, we cannot find those decorated features in the Horn of Africa, neither in Djibouti where we deal only with engravings (Joussaume 1987), nor in Eritrea (CALEGARI 1999). We have to recall here what we have mentioned earlier: the similarity between the cows' painted neck of Karin Heegan and the cows' decorations of Las Geel. However, we cannot find at Las Geel the barbed stroke linking the two horns' ends on the bovines of Karin Heegan, nor can we find the small filiform or triangular appendages hooked at one horn's end, like at Chabbé or on the same cow at Karin Heegan.

\section{Regional Context}

We saw only a few decorated shelters during our reconnaissance in Somaliland in November-December 2002. Besides the extraordinary site of Las Geel, the others show only modest works belonging to several periods. At the Western end of the big limestone massif in the Goolis hills, near the spur of Gaan Libah, the cave 1 of Garba Keyle, excavated in the 1930's by the Major Glover, reveals lithic industries attributed to Somaliland Wilton by J. D. Clark (CLARK 1954: 349). At the caves entrance, we can see on the two walls red and black paintings worn away and stylized that don't match with the ones from Las Geel. They are elephants, giraffes, antelopes, and maybe a lion and a bovine. Some later engravings representing dromedaries were noticed on the right wall at the entrance, where most are to be found.

The unpublished shelters of Diymolhe or of Dhagaxa Sumadaha Le to the South of Berbera, only show tribal signs painted in red or black and are probably of a recent age. Other decorated shelters have been of course mentioned during several European or American missions in British and Italian Somalia but the graphic representations or pictures given by Clark or other authors are very few. In his PhD dissertation de- 
fended in 2002, D. Bouakaze-Khan counts 21 decorated sites in Somalia and Somaliland and can only reproduce few plates of the tribal signs coming mostly from the study made by S.A. Brandt in Central Somalia in the shelters opened on the hillside of the inselberg of Buur Heybe, already studied by Graziozi then by Clark. He also reproduces drawings of panels from Karin Heegan already published by Brandt (BRANDT \& CARDER 1987). Finally, we will add to this general overview the engraved rock of Hor Jog on the Eastern side of the highest peak in the massif of Wagar, about $50 \mathrm{~km}$ from Sheikh. It is a small block of less than $1 \mathrm{~m}^{3}$ that carries on its upper side two engraved humpless bovines with claw-shaped horns, without udder and, apart from this significant detail, that show an outline and some proportions close to the carved bovines from Galma in the Sidamo (Joussaume et al. 1994).

\section{Conclusions and Prospects}

The discovery of Las Geel on the $4^{\text {th }}$ of December 2002 was for our team a great moment as it is true that this set of ten decorated shelters is exceptional by the quality, the originality and the preservation of most of the rock painted works. We could only spend a few hours on the site and, moreover, part of the shelters could not be photographed because of the presence of aggressive wasp swarms. It was the case especially in one of the two shelters located to the North and which, seen with binoculars, seem very rich in very well preserved animal representations. Once this problem is solved, we hope to have access to these shelters and undertake their detailed study. This is the target we set ourselves with the agreement of the Somalilandese Authorities for a future mission in 2003. Meanwhile, we have encouraged the Ministry of Culture and Tourism to take surveillance measures for the site.

The site of Las Geel is certainly one of the most outstanding sites of the Horn of Africa. The particular drawing of the female bovines can make of it the eponymous site of a new cave art style that must now be placed in time in relation to the other regional sets already studied (Djibouti, Eritrea, Ethiopia), not forgetting Yemen and Arabian peninsula.

Many rocky massifs auspicious to this artistical expression that scattered the Repbulic of Somaliland have been minimally explored since western researchers became interested in these lands. It is thus likely that new discoveries will give us a better knowledge of this pre- or protohistoric art.

\section{Bibliography}

Bouakaze-Khan, D. 2002. L'art rupestre de la Corne de l'Afrique. Etude globale dans son contexte archéologique et anthropologique. Modèle d'interprétation. Unpublished Thesis, University of Paris 1-PanthéonSorbonne, Paris.

Brandt, S. A. 1986. The Upper Pleistocene and early Holocene prehistory of the Horn of Africa. The African Archaeological Review 4, 41-82.

Brandt, S. A. 1989. L'Age de la Pierre en Somalie. L'Anthropologie (Paris) 94 (3), 459-482.

Brandt, S. A. \& Carder, N. 1987. Pastoral rock art in the Horn of Africa: Making sense of udder chaos. World Archaeology 19 (2), 194-213

Brandt, S. A., Brook, G. A. \& Gresham, T. H. 1984. Quaternary Paleooenvironments and Prehistoric Human Occupation of Northern Somalia. In: Labahn, T. (ed.), Proceedings of the Second International Congress of Somali Studies, vol. II, Helmut Buske Verlag, Hamburg, 1984, pp. 7-22.

Calegari, J. 1999. L'arte rupestre dell'Eritrea. Repertorio ragionato ed esegesi iconografica. Memorie delle Società Italiana di Scienze Naturali e del Museo Civico di Storia Naturale di Milano, vol. XXIX, fasc. 1. Milano.

Cervicek, P. 1979. Some African affinities of Arabian rock art. Rassegna di studi ethiopici XXVII, 5-12.

Clark J. D. 1954. The prehistoric cultures of the Horn of Africa. Cambridge University Press, Cambridge.

Joussaume, R. 1981. L'art rupestre de l'Ethiopie. In: Roubet, C., Hugot, H.-J. \& Souville, G. (eds.), Préhistoire africaine. Mélanges offerts au doyen Balout. Synthèse $n^{\circ} 6$. Éditions A.D.P.F., Paris, pp. 159-175.

Joussaume R. 1987. Gravures rupestres en République de Djibouti. Bull. du Groupe vendéen d'études préhistoriques 17, 24-45.

Joussaume, R. 1989. Gravures rupestres en République de Djibouti. Bull. de l'ISERST, Djibouti, n², 105-129.

Joussaume, R. (ed.) 1995. Tiya-L'Ethiopie des mégalithes. Du biface à l'ant rupestre dans la Corne de l'A frique. Association des publications chauvinoises, Chauvigny.

Joussaume, R., Barbier, S. \& Gutherz, X. 1994. L'art rupestre du Sidamo (Ethiopie). International Newsletter on Rock Art 9 , $7-11$.

Le Quellec, J.-L. \& Gizachew, A. 2001. New sites of South Ethiopian rock engravings: Godana Kinjo, Ejersa Gara Hallo, and remarks on the Sappe-Galma school. Annales d'Ethiopie XVII, 205-224. 